\title{
Cytotoxicity, Hemolysis and Acute In Vivo Toxicity of Dendrimers Based on Melamine, Candidate Vehicles for Drug Delivery
}

\author{
Hui-Ting Chen, ${ }^{1}$ Michael F. Neerman, ${ }^{1}$ Alan R. Parrish, ${ }^{*}, 2$ and Eric E. Simanek ${ }^{*, 1}$ \\ ${ }^{1}$ Department of Chemistry, Texas A\&M University, College Station, TX 77843-3255 \\ ${ }^{2}$ Department of Toxicology and Medical Pharmacology, Texas A\&M University Health Science Center, \\ College Station, TX 77843-3255
}

\section{Experimental}

Computation. Energy-minimized structures of $\mathbf{2}$ and $\mathbf{7}$ (gas phase) were obtained using the software package Cerius ${ }^{2} 4.6$ by Accelrys, Inc (June 2000, San Diego). The pcff second-generation force field in the open Force Field (OFF) program was used in minimizations and dynamics. The structures were initially minimized in the fully extended conformation. Constant volume and temperature (NVT) molecular dynamics (MD) calculations were then performed on the minimized extended structures via simulated annealing. The simulated annealing was carried out for $840.0 \mathrm{ps,} \mathrm{over} \mathrm{a} \mathrm{temperature} \mathrm{range} \mathrm{of}$ 300-1000 K, with $\Delta \mathrm{T}=50 \mathrm{~K}$, using the Nosé temperature thermostat, a relaxation time of $0.1 \mathrm{ps}$, and a time step of 0.001 ps. The dendrimers were minimized after each anneal cycle, resulting in 300 and 86 minimized structures of 2 and 7, respectively.

Hemolysis study. ${ }^{7}$ One milliliter of blood was collected from a male C3H mouse via cardiac puncture. From this a 2\% w/v red blood cell (RBC) solution was prepared and centrifuged at $1500 \mathrm{rpm}$ for $10 \mathrm{~min}$ at $4{ }^{\circ} \mathrm{C}$. The plasma supernatant was removed and the erythrocytes were resuspended in ice cold PBS. The cells were again centrifuged at $1500 \mathrm{rpm}$ for $10 \mathrm{~min}$ at $4{ }^{\circ} \mathrm{C}$. This was repeated two more times to ensure the removal of any released hemoglobin. After the supernatant was removed following the last wash, the cells were resuspended in PBS to get a 2\% w/v RBC solution. The dendrimers and the reference polymer dextran were also prepared in PBS via serial dilutions. One hundred microliters of the dendrimers or the reference polymer, dextran, prepared in PBS (0.001-10 
$\mathrm{mg} / \mathrm{ml}$ ) were added to $100 \mu \mathrm{l}$ of the $2 \% \mathrm{w} / \mathrm{v}$ RBC solution in a 96-well plate and incubated for 1 or $24 \mathrm{~h}$ at $37^{\circ} \mathrm{C}$. Complete hemolysis was attained using a $2 \% \mathrm{v} / \mathrm{v}$ Triton-X yielding the $100 \%$ control value (positive control). After incubation, the plates were centrifuged and the supernatants were transferred to a new 96-well plate. The release of hemoglobin was determined by spectrophotometric analysis of the supernatant at $550 \mathrm{~nm}$. Results were expressed as the amount of hemoglobin release induced by the conjugates as a percentage of the total. ${ }^{8}$

MTT Assay. 9,10 The cell viability assay was performed on the rat liver cell line Clone 9. The Clone 9 cell line was a generous gift of Dr. Robert Burghardt of Texas A\&M University (College Station, TX). The cells were maintained in Ham's F12 media supplemented with 10\% fetal bovine serum $/ 1 \%$ PenStrep at $37{ }^{\circ} \mathrm{C}$ in a humidified atmosphere containing $5 \% \mathrm{CO}_{2} / 95 \%$ relative humidity . Clone 9 cells were grown in T-25 $\mathrm{cm}^{2}$ culture flasks to confluency and then were seeded at $1 \times 10^{5}$ cells/ml in 96-well plates and maintained in the conditions previously mentioned. Twenty four hours later, the medium was aspirated and replaced with $100 \mu \mathrm{l}$ of fresh medium containing dextran (negative control) or dendrimer (0-10 mg/ml). Following $24 \mathrm{~h}$ of incubation, the old medium was removed via aspiration and replaced with $200 \mu \mathrm{l}$ of fresh media. MTT solution (3-(4,5-dimethythiazole-2-yl)-2,5diphenyltetrazolium bromide) was added ( $5 \mathrm{mg} / \mathrm{ml}, 20 \mu \mathrm{l})$ to each well and incubated for a further $4 \mathrm{~h}$. After such time, the medium was removed and $100 \mu \mathrm{l}$ of dimethylsulfoxide (DMSO) was added and the optical density at $550 \mathrm{~nm}$ was measured. Cell viability was expressed as a percent of untreated controls. The basis of this assay is that MTT, a water-soluble tetrazolium dye, is reduced by mitochondrial dehydrogenase enzymes in living cells to MTX, a water-insoluble formazan salt that will precipitate out as purple crystals while dead or dying cells will exhibit reduced or no crystal formation.

Microscopy. Clone 9 cells were grown to confluency in 12 well plates and incubated with either 1 or $10 \mathrm{mg} / \mathrm{ml}$ of dendrimer 2 or 7 for $3 \mathrm{~h}$. Changes in cell morphology and detachment of the cells were assessed using a Zeiss Axiovert 25 inverse phase contrast microscope (Zeiss, Thornwood, NY) equipped with an objective (LD A-Plan Ph1/Var1, Zeiss, Thornwood, NY) of 32X magnification. 
General Synthetic Methods. Solvents and reagents were reagent grade and used without further purification. ${ }^{1} \mathrm{H}$ NMR (300 MHz or $500 \mathrm{MHz}$ ) and proton decoupled ${ }^{13} \mathrm{C}$ NMR spectra (75 MHz or 125 $\mathrm{MHz}$ ) were recorded with $\mathrm{CDCl}_{3}, \mathrm{CDCl}_{3} / \mathrm{MeOH}-\mathrm{d}_{4}(10: 1)$, or $\mathrm{MeOH}-\mathrm{d}_{4} / \mathrm{D}_{2} \mathrm{O}(2: 1)$ as internal standards.

Synthesis of Dendrimer 1. Intermediate 16 (0.54 g, $0.5 \mathrm{mmol})$ and polymer-supported BEMP (2.7 g, $6.0 \mathrm{mml})$ were mixed in 1,1,2 trichloroethane/i-PrOH (5/1, $30 \mathrm{~mL})$ for $10 \mathrm{~min}$ at room temperature. To the mixture was added compound 11 (5.54 g, $3.05 \mathrm{mmol}$ ) and the reaction temperature was raised to $80{ }^{\circ} \mathrm{C}$. After stirring for 3 days, the supported base was removed, the filtrate was evaporated and purified by column chromatography ( $\left.\mathrm{MeOH} / \mathrm{CH}_{2} \mathrm{Cl}_{2}=1 / 10, \mathrm{R}_{f}=0.35\right)$ to obtain 1 (5.3 g,

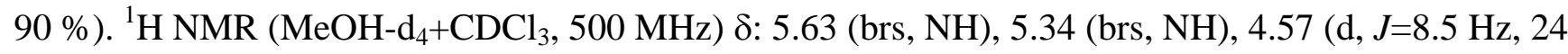
Hz), 3.69 (br, 72 H), 3.37 (br, 96 H), 3.16 (br, 24 H), 2.94 (br, 96 H), 2.68 (br, 24 H), 1.59 (br, 132 H),

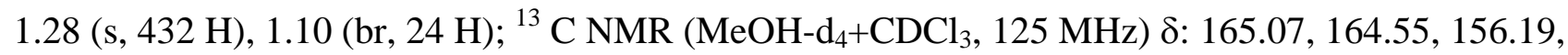
78.85, 45.77, 43.15, 42.96, 42.72, 42.47, 37.81, 37.02, 29.55, 28.05, 27.62. MS (MALDI-TOF): calcd for $\mathrm{C}_{558} \mathrm{H}_{984} \mathrm{~N}_{180} \mathrm{O}_{96}: 11750.9320$; found $5869.7(\mathrm{M}+2 \mathrm{H})^{2+}, 11764.54(\mathrm{M}+\mathrm{H})^{+}$.

Dendrimer 2. Dendrimer 1 (1.17 g, $100 \mu \mathrm{mol})$ was stirred in solution of TFA/ $\mathrm{CH}_{2} \mathrm{Cl}_{2} / \mathrm{MeOH}$ (7.5 mL/5 mL/5 mL) for $24 \mathrm{hr}$ at room temperature. The solution was neutralized with triethylamine. The reaction volatiles were removed by evaporation to give yellow oil. The oil was loaded into dialysis bag (MWCO=3500) and dialyzed again deionized water for $24 \mathrm{hr}$. The solution was collected and condensed in vacuo to give gold foam. (0.66 g, $95 \%) .{ }^{1} \mathrm{H}$ NMR (MeOH-d $\left.{ }_{4}+\mathrm{D}_{2} \mathrm{O}, 500 \mathrm{MHz}\right) \delta: 4.8$ (br, $24 \mathrm{H})$, 3.85-3.51 (m, $168 \mathrm{H}), 3.04$ (br, $24 \mathrm{H}), 2.72$ (br, $120 \mathrm{H}), 1.82$ (br, $132 \mathrm{H}), 1.18$ (br, $24 \mathrm{H}) .{ }^{13} \mathrm{C}$

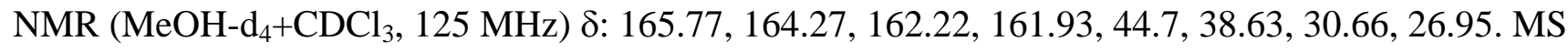
(MALDI-TOF): calcd for $\mathrm{C}_{318} \mathrm{H}_{600} \mathrm{~N}_{180}$ : 6945.37; found $6943.89(\mathrm{M}+\mathrm{H})^{+}, 6965.62(\mathrm{M}+\mathrm{Na})^{+}$.

Dendrimer 3. 1H-pyrazole-1-carboxamidine hydrochloride (1.421 g, 9.6 mmol) and DIPEA (3.3 mL, $19.2 \mathrm{mmol}$ ) were mixed in acetonitrile (3 mL). After the solution became clear, a solution of 2 (138.9 mg, $20 \mathrm{mmol}$ ) in $3 \mathrm{~mL}$ of deionized water was added. The reaction was stirred for 5 days at room 
temperature. The solvents were removed andthe residue was dissolved in deionized water (20 mL). The solution was dialyzed (molecular weight 3500 cut off) against deionized water for 1 day before removal of the solvent to give oil. The oil was dissolved in $\mathrm{MeOH}$ and precipitated from diethyl ether to get white solid collected by centrifugation (183.5 mg). MS (MALDI-TOF): calcd for $\mathrm{C}_{366} \mathrm{H}_{696} \mathrm{~N}_{276}$ : 8963.29; found $8989.87(\mathrm{M}+\mathrm{H})^{+}$.

Dendrimer 4. 1,3-Propanesultone (1.20 g, $9.6 \mathrm{mmol}$ ) was dissolved in acetonitrile (3 mL). Dendrimer 2 (138.9 mg, $20 \mu \mathrm{mol}$ ) dissolved in $3 \mathrm{~mL}$ of deionized water was added. When the solution became homogeneous, DIPEA (3.3 mL, $19.2 \mathrm{mmol}$ ) was added, and the reaction mixture was stirred under nitrogen for 5 days at room temperature. The solvents were removed and the residue was dissolved in 20mL of deionized. This sample was diazlyzed (molecular weight 3500 cut off) against deionized water for 1 day. The solution was collected and condensed to give oil. The oil was dissolved in $2 \mathrm{~mL}$ of deionized water and $10 \mathrm{~mL}$ of $\mathrm{MeOH}$ were added to form white cloudy suspension that was collected by centrifugation (185.4 mg). MS (MALDI-TOF): calcd for $\mathrm{C}_{387} \mathrm{H}_{738} \mathrm{~N}_{180} \mathrm{O}_{69} \mathrm{~S}_{23}$ : 9754.66; found $9786.91(\mathrm{M}+\mathrm{H})^{+}$.

Dendrimer 5. Diethyl vinyl phosphonate $(1.53 \mathrm{~mL}, 9.6 \mathrm{~mL})$ was dissolved in $3 \mathrm{~mL}$ of acetonitrile. To the solution was added solution of 2 (138.9 mg, $20 \mathrm{mmol})$ in $3 \mathrm{~mL}$ of distilled water. The reaction mixture was stirred under nitrogen for 5 days at room temperature. The diethyl phosphonate was obtained as an oil by removing solvent. MS (MALDI-TOF): calcd for $\mathrm{C}_{732} \mathrm{H}_{1497} \mathrm{~N}_{180} \mathrm{O}_{206} \mathrm{P}_{69}$ : 18254.99; found $18200.8(\mathrm{M}+\mathrm{H})^{+}$.

This oil was suspended in $20 \% \mathrm{HCl}(10 \mathrm{ml})$ and refluxed for 1 day. The reaction solution was dialyzed (molecular weight 3500 cut off) against deionized water for 1 day. The solution was collected and condensed in vacuo to give foam (190 mg). MS (MALDI-TOF): calcd for $\mathrm{C}_{456} \mathrm{H}_{945} \mathrm{~N}_{180} \mathrm{O}_{207} \mathrm{P}_{69}$ : 14399.65; found $14285.03(\mathrm{M}+\mathrm{H})^{+}$.

Dendrimer 6. Succinic acid (970.0mg, $9.6 \mathrm{mmol}$ ) was dissolved in Acetonitrile/THF (3 mL/1 $\mathrm{mL}$ ), and then the solution of $\mathbf{2}(138.9 \mathrm{mg}, 20 \mu \mathrm{mol})$ in $3 \mathrm{~mL}$ of deionized $\mathrm{H}_{2} \mathrm{O}$ was added. DIPEA (3.3 
$\mathrm{mL}, 19.2 \mathrm{mmol}$ ) was added and the reaction yellowed and was stirred under nitrogen for 5 days at room temperature. The solvents were removed and the residue was diluted with deionized water $(20 \mathrm{~mL})$. Dialysis (molecular weight 3500 cut off) against deionized water for 1 day produced a cloudy solution. The contents were collected and solvent evaporated in vacuo to give oil. The oil was dissolved in $\mathrm{MeOH}$ and precipitated from diethyl ether to get white solid (154.1 mg) that was collected by centrifugation. MS (MALDI-TOF): calcd for $\mathrm{C}_{510} \mathrm{H}_{792} \mathrm{~N}_{180} \mathrm{O}_{144}$ : 11748.87; found $11769.88(\mathrm{M}+\mathrm{H})^{+}$.

Dendrimer 7. M-PEG-SPA (576 mg, $288 \mu \mathrm{mol}$ ) was stirred in MeOH (3 mL) with a solution of 2 (48.2 mg, $6.9 \mu \mathrm{mol})$ in $3 \mathrm{~mL}$ of deionized water and DIPEA $(0.1 \mathrm{~mL}, 576 \mu \mathrm{mol})$ for 5 days at room temperature. Removal of the solvent gave a residue that was diluted with $20 \mathrm{~mL}$ of deionized water and dialyzed (molecular weight 3500 cut off) against deionized water for 1 day. The solution was collected and evaporated to give oil, that was redissolved in water and precipitated from diethylether to get white solid (355.8 mg) that could be collected by centrifugation. MS (MALDI-TOF): calcd for 26 PEG species (based on PEG=2000): 58945.37; found 57972.78 $(\mathrm{M}+\mathrm{H})^{+}$.

Intermediate 8. A solution of triamine $(13.4 \mathrm{~g}, 0.1 \mathrm{~mol})$ and triethylamine $(42.6 \mathrm{~mL}, 0.3 \mathrm{~mol})$ in THF (500 mL) was cooled in an ice bath and stirred as a solution of 2-[[tert-butoxycarbonyl]oxy]imino]-2-phenylacetonitrile (BOC-ON: $50 \mathrm{~g}, 0.2 \mathrm{~mol}$ ) in THF (500 mL) was added over $40 \mathrm{~min}$. After stirring for $2 \mathrm{hr}$ in the ice bath, the solution was warmed to room temperature and stirred overnight. The solvent was removed by evaporation to give golden oil which was dissolved in $\mathrm{CHCl}_{3}$ and washed with $5 \% \mathrm{HCl}$ solution (x3), $5 \% \mathrm{NaOH}(\mathrm{W} / \mathrm{V})$ solution (x4) and brine (x3). The organic layer was dried over anhydrous $\mathrm{MgSO}_{4}$, filtered, and the solvents were removed. The residue was purified by column chromatography $\left(\mathrm{MeOH} / \mathrm{CH}_{2} \mathrm{Cl}_{2}=1 / 10, \mathrm{R}_{\mathrm{f}}=0.21\right)$ to provide 8 . (29.4 g, $\left.89 \%\right)$. ${ }^{1} \mathrm{H}$

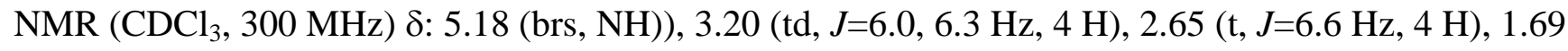
(brs, NH), 1.65 (m, 4 H), 1.43 (s, 18H); ${ }^{13}$ C NMR (CDCl3, 75 Hz) 8: 156.38, 79.27, 47.57, 39.09, 29.91, 28.64. MS (ESI-TOF): calcd for $\mathrm{C}_{16} \mathrm{H}_{33} \mathrm{~N}_{3} \mathrm{O}_{4}$ : 331.25; found $332.25(\mathrm{M}+\mathrm{H})^{+}$. 
Intermediate 9. To an iced solution of 8 (10.0 g, $30.2 \mathrm{mmol})$ in $\mathrm{THF} / \mathrm{CHCl}_{3}(1: 1,50 \mathrm{~mL})$, trichlorotriazine (2.7 g, $14.4 \mathrm{mmol})$ and DIPEA (10.7 mL, $60.0 \mathrm{mmol}$ ) were added. The mixture was warmed to room temperature and stirred for $2 \mathrm{hr}$. The white solid was removed by filtration, and the filtrate was evaporated to give an oil. The oil was dissolved in $\mathrm{CHCl}_{3}$ again and washed by $5 \% \mathrm{HCl}$ solution (x3), $5 \% \mathrm{NaOH}\left(\mathrm{W} / \mathrm{V}\right.$ ) solution (x4) and brine (x3). The organic layer was dried over $\mathrm{MgSO}_{4}$, filtered and the solvent was removed to give 9 as foam. (10.9 g, $98 \%, \mathrm{MeOH} / \mathrm{CH}_{2} \mathrm{Cl}_{2}=1 / 20 \mathrm{R}_{f}=0.25$ ). ${ }^{1} \mathrm{H} \mathrm{NMR}\left(\mathrm{CDCl}_{3}, 300 \mathrm{MHz}\right.$ ) 8: 5.65 (brs, NH), 5.30 (brs, NH), 3.60 (t, J=6.0 Hz, 4 H), 3.50 (t, J=7.2

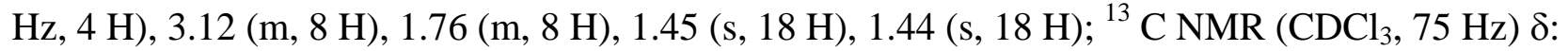
169.34, 165.11, 156.66, 79.69, 79.28, 45.15, 44.07, 38.74, 37.22, 28.92, 28.89, 28.48. MS (ESI-TOF): calcd for $\mathrm{C}_{35} \mathrm{H}_{64} \mathrm{ClN}_{9} \mathrm{O}_{8}$ : 773.46; found $774.46(\mathrm{M}+\mathrm{H})^{+}$.

Intemediate 10. To the solution of $9(9.8 \mathrm{~g}, 12.7 \mathrm{mmol})$ in $\mathrm{THF} / \mathrm{CHCl}_{3} / \mathrm{MeOH}(5: 5: 1,110 \mathrm{~mL})$ was added 4-(aminomethyl) piperidine (4.5 g, $29.0 \mathrm{mmol})$. The suspension was stirred at room temperature for $20 \mathrm{hr}$. A white solid was removed by filtration and the filtrate was evaporated to give oil. The oil was dissolved in $\mathrm{CHCl}_{3}$ again and washed by $5 \% \mathrm{HCl}$ solution (x3), $5 \% \mathrm{NaOH}(\mathrm{W} / \mathrm{V}$ ) solution (x4) and brine (x3). The organic layer was dried over $\mathrm{MgSO}_{4}$, filtered and condensed to afford foam as desired compound 10, $\left(\mathrm{MeOH} / \mathrm{CH}_{2} \mathrm{Cl}_{2}=1 / 10, \mathrm{R}_{f}=0.13\right)$ yield 10.0 g. (93 \%) ${ }^{1} \mathrm{H} \mathrm{NMR}(\mathrm{MeOH}-$

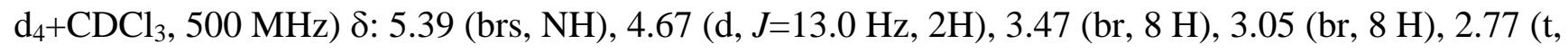
$J=12.3 \mathrm{~Hz}, 2 \mathrm{H}), 2.56$ (d, J=5.5 Hz, 2H), 1.69 (br, $10 \mathrm{H}), 1.53$ (br, $1 \mathrm{H}), 1.38$ (s, $36 \mathrm{H}), 1.09$ (m, $2 \mathrm{H}) ;{ }^{13}$

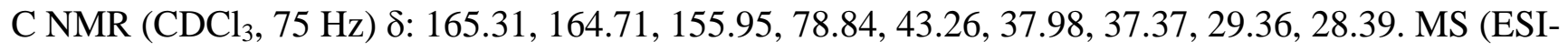
TOF): calcd for $\mathrm{C}_{41} \mathrm{H}_{77} \mathrm{~N}_{11} \mathrm{O}_{8}$ : 851.60; found $852.60(\mathrm{M}+\mathrm{H})^{+}$.

Intermediate 11. To the solution of $\mathbf{1 0}(6.1 \mathrm{~g}, 7.2 \mathrm{mmol})$ in $\mathrm{THF} / \mathrm{CHCl}_{3} / \mathrm{MeOH}(5: 5: 1,110 \mathrm{~mL})$ was added trichlorotriazine (664.0 mg, $3.6 \mathrm{mmol})$ and DIPEA (2.6 mL, $14.3 \mathrm{mmol})$. The mixture was stirred at room temperature for $24 \mathrm{hr}$. After removing volatile components, the foam was purified through column chromatography to afford desired compound $\mathbf{1 1}$ as white foam. (6.0 g, 93 \%, 
EA/DCM=1/1, $\left.\mathrm{R}_{f}=0.33\right) .{ }^{1} \mathrm{H}$ NMR $\left(\mathrm{CDCl}_{3}+\mathrm{MeOH}-\mathrm{d}_{4}, 500 \mathrm{MHz}\right) \delta: 4.58$ (m, $\left.4 \mathrm{H}\right), 3.39$ (brs, $\left.16 \mathrm{H}\right)$,

3.17 (m, 4 H), 2.95 (brs, 16 H), 2.67 (m, 4 H), 1.62 (m, 22 H), 1.29 (s, 72 H), 1.06 (m, 4 H); ${ }^{13} \mathrm{C}$ NMR

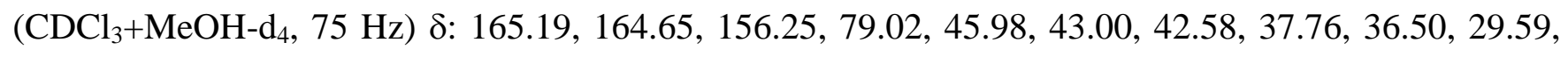
28.15. MS (MALDI-TOF): calcd for $\mathrm{C}_{85} \mathrm{H}_{152} \mathrm{ClN}_{25} \mathrm{O}_{16}$ : 1815.73 ; found $1814.19(\mathrm{M})^{+}, 1836.73(\mathrm{M}+\mathrm{Na})^{+}$.

Intermediate 12. Boc-protected piperazine (1.57 g, $8.3 \mathrm{mmol})$ and trichlorotriazine (0.5 g, 2.5 mmol) were mixed in $60 \mathrm{~mL}$ of THF/DMF (10/1). DIPEA (2.2 mL, $12.5 \mathrm{mmol})$ was added and the reaction was stirred at room temperature for $2 \mathrm{hr}$, then at $80^{\circ} \mathrm{C}$ for $5 \mathrm{hr}$. After being cooled to room temperature, a white solid was collected by filtration and washed with THF before drying under vacuum to yield compound $1.53 \mathrm{~g}$ of $12\left(97 \%, \mathrm{MeOH} / \mathrm{CH}_{2} \mathrm{Cl}_{2}=1 / 50, \mathrm{R}_{f}=0.26\right) .{ }^{1} \mathrm{H} \mathrm{NMR}\left(\mathrm{CDCl}_{3}, 300 \mathrm{MHz}\right) \delta$ :

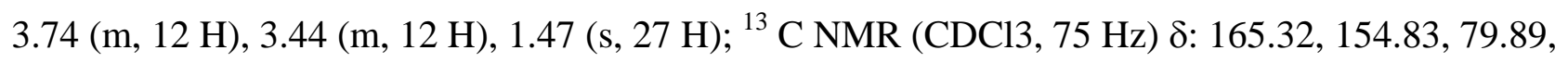
42.90, 28.41. MS (ESI-TOF): calcd for $\mathrm{C}_{30} \mathrm{H}_{51} \mathrm{~N}_{9} \mathrm{O}_{6}$ : 633.40; found 634.40. $(\mathrm{M}+\mathrm{H})^{+}$.

Intermediate 13. Intermediate 12 (2.1 g, $3.3 \mathrm{mmol})$ was dissolved in 20mL TFA/DCM (1:1). After $4 \mathrm{hr}$ stirring at room temperature, the volatile components were removed by evaporation. The residue was dissolved in $\mathrm{MeOH}$ and neutralized by adding trimethylamine, and the solvent was subsequently evaporated. After the procedure was repeated by three times, a yellow oil containing 13 was obtained. (2.22 g, quantitive) ${ }^{1} \mathrm{H} \mathrm{NMR}\left(\mathrm{MeOH}_{-} \mathrm{d}_{4}, 500 \mathrm{MHz}\right)$ 8: 4.042 (t, $\left.5.3 \mathrm{~Hz}, 12 \mathrm{H}\right), 3.235$ (t, $5.3 \mathrm{~Hz}, 12 \mathrm{H}) ;{ }^{13} \mathrm{C}$ NMR (MeOH-d $\left.4,125 \mathrm{~Hz}\right) \delta:$ 166.61, 44.41, 41.16. MS (ESI-TOF): cacld for $\mathrm{C}_{15} \mathrm{H}_{27} \mathrm{~N}_{9}$ : 333.24; found $334.25(\mathrm{M}+\mathrm{H})^{+}$.

Intermediate 14. Boc-protected piperazine (3.99 g, $21 \mathrm{mmol})$ and trichlorotriazine (1.86 g, $10.0 \mathrm{mmol})$ were mixed in THF (100 mL). DIPEA (3.7 mL, $30.0 \mathrm{mmol})$ was added and the reaction was stirred at room temperature for $24 \mathrm{hr}$. A white solid was removed by filtration and the filtrate was evaporated to provide a residue. Following chromatography $\left(\mathrm{MeOH} / \mathrm{CH}_{2} \mathrm{Cl}_{2}=1 / 50, \mathrm{R}_{f}=0.36\right) 14$ was obtained as a white solid in 97\% yield. ${ }^{1} \mathrm{H} \mathrm{NMR}\left(\mathrm{CDCl}_{3}, 300 \mathrm{MHz}\right)$ 8: 3.755 (br s, $\left.8 \mathrm{H}\right), 3.444$ (br s, 8 
H), 1.456 (s, $18 \mathrm{H}) ;{ }^{13} \mathrm{C} \mathrm{NMR}\left(\mathrm{CDCl}_{3}, 75 \mathrm{~Hz}\right) \delta:$ 169.92, 164.69, 154.86, 80.48, 43.50, 28.61. MS (ESITOF): calcd for $\mathrm{C}_{21} \mathrm{H}_{34} \mathrm{ClN}_{7} \mathrm{O}_{4}$ : 483.24; found $484.25(\mathrm{M}+\mathrm{H})^{+}, 486.26(\mathrm{M}+\mathrm{H})^{+}$.

Intermediate 15. Intermediate 13 (0.58 g, $1.74 \mathrm{mmol})$ was mixed with DIPEA (1 mL) in $20 \mathrm{~mL}$ of 1,1,2-trichloroethane/MeOH (1:1) for 5 min. Intermediate 14 (3.0 g, $6.2 \mathrm{mmol})$ and $\mathrm{K}_{2} \mathrm{CO}_{3}$ (5.0 g, 36 mmol) were added to the mixture. The mixture was stirred under reflux for $24 \mathrm{hr}$. After cooling to room temperature, the solid was removed by filtration and washed with $\mathrm{CH}_{2} \mathrm{Cl}_{2}$ for several times. The filtrate was collected and evaporated to obtain solid. Purification by column chromatography $\left(\mathrm{MeOH} / \mathrm{CH}_{2} \mathrm{Cl}_{2}=1 / 20, \mathrm{R}_{f}=0.5\right)$ afforded 15 as a white solid (2.51 g, 86 \%). ${ }^{1} \mathrm{H} \mathrm{NMR}\left(\mathrm{CDCl}_{3}+\mathrm{MeOH}_{-} \mathrm{d}_{4}\right.$,

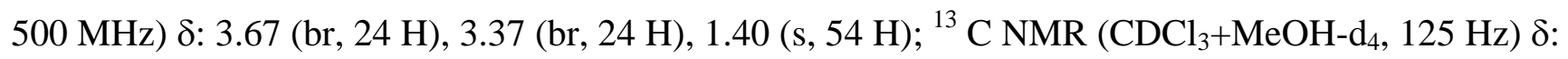
165.11, 154.93, 80.15, 42.93, 42.8, 28.1. MS (MALDI-TOF): calcd for $\mathrm{C}_{78} \mathrm{H}_{126} \mathrm{~N}_{30} \mathrm{O}_{12}$ : 1676.03; found $1677.70(\mathrm{M}+\mathrm{H})^{+}$

The Core (16). Intermediate 15 (1.86g, $1.1 \mathrm{mmol})$ was stirred in $\mathrm{CH}_{2} \mathrm{Cl}_{2} / \mathrm{MeOH}(15 \mathrm{~mL} / 2 \mathrm{~mL})$. Trifluoroacetic acid (12 mL) was added to the iced solution. After stirring for $24 \mathrm{hr}$, the volatiles were evaporated to provide an oil. The oil was partitioned between $\mathrm{CHCl}_{3}$ and $5 \% \mathrm{NaOH}(a q)$. The organic layer was washed by $5 \% \mathrm{NaOH}(\mathrm{x} 3)$ and brine (x3), and then dried over $\mathrm{MgSO}_{4}$. After filtering, the solvent was evaporated to afford 16 as a light yellow solid (1.08 g, 91\%). ${ }^{1} \mathrm{H} \mathrm{NMR}\left(\mathrm{CDCl}_{3}+\mathrm{MeOH}-\mathrm{d}_{4}\right.$, $300 \mathrm{MHz}) \delta: 3.68$ (br, $12 \mathrm{H}), 3.63$ (m, $12 \mathrm{H}), 2.73$ (m, $12 \mathrm{H}) ;{ }^{13} \mathrm{C} \mathrm{NMR}\left(\mathrm{CDCl}_{3}+\mathrm{MeOH}-\mathrm{d}_{4}, 75 \mathrm{~Hz}\right) \delta$ : 165.11, 165.01, 45.17, 43.62, 42.81. MS (ESI-TOF): calcd for $\mathrm{C}_{48} \mathrm{H}_{78} \mathrm{~N}_{30}$ : 1074.70; found 538.37 $(\mathrm{M}+2 \mathrm{H})^{2+}, 1075.75(\mathrm{M}+\mathrm{H})^{+}$.

\section{Supplementary Figure 1. Blood} urea nitrogen (BUN, panel a) and alanine transaminase activity (ALT, panel b) which are diagnostic for kidney and liver toxicity,
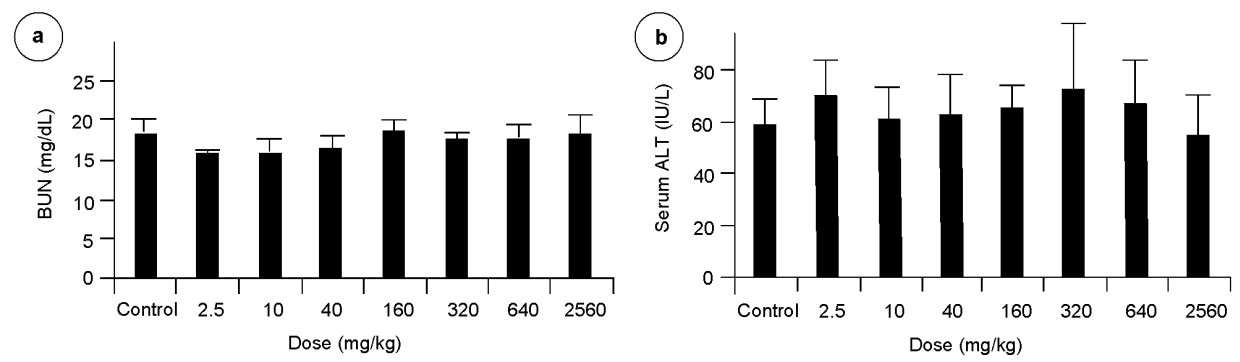
respectively. 